\title{
Actualization of Nigeria's Vision 20:2020 Through Entrepreneurial Development Culture
}

\author{
Omoankhanlen, Joseph Akhigbe and B.S.O. Ighalo, Ambrose Alli University, Nigeria
}

\begin{abstract}
A worldwide consensus on the critical role of competitive markets and entrepreneurs in economic development has emerged in the last decade. In developing countries, the primary barriers to economic growth is often not so much a scarcity of capital, labour or land, as it is a scarcity of both the dynamic entrepreneurs that bring these together and the markets and mechanisms that can facilitate them in this task. The purpose of this paper is to describe the essential features of an entrepreneurial development culture in Nigeria, as it relates to vision 20:2020 and provides a sense of direction for Nigerian vision 20:2020 planners, makers of policies and government - for them to quickly realize and capitalize on entrepreneurial development culture, since it is a tool for any economy development - thus, it implies that entrepreneurial development culture is indispensable if Nigeria must actualize vision 20:2020. Conclusively, the attainment of the Nigeria's vision $20-$ 2020 and other development milieu such as Seven - Point Agenda, National Economic Empowerment and Development Strategy (NEEDS) and Millennium Development Goals (MDGS) etc can hardly be achieved without a very strong backing of entrepreneurial development culture. We therefore argue that entrepreneurial development culture that is based on "indigenous entrepreneur" should stand as the basis for our development as a nation.
\end{abstract}

\section{Introduction}

Modern nations are under ever increasing competitive pressure to be reckoned with amongst the greatest economies of the world. The 1990s saw the world entering an era of global competition, meanwhile, as competition intensifies; the pursuit of entrepreneurial development becomes vital to nations aspiring to achieve competitive advantage (Eisenhardt and Martin, 2000). Economists have long believed that entrepreneurs push back the business frontier by challenging existing practices and policies. Entrepreneurial development culture is often the missing performance factors in poor countries - where economies are stagnant or regressive. Developing countries trapped in economic droughts need to be irrigated by the entrepreneurial development culture. Besides inventing new products and services, or new ways of delivering things in the economy, entrepreneurs create new business models and economic structures. Through their willingness to "do things differently," entrepreneur can "change the economic and social landscape," by acting as an agent of innovation, they can transform a static economy and move it forward.

Nigeria's vision is to become a dominant player in the world economic arena by the year 2020; hence, her aspiration is to be classified among the greatest first twenty economies in the globe by 2020. Nigeria with abundant resources (human and natural resources; largest black nation; 8th largest oil producer and 6th largest deposit of gas; 34th solid minerals; 
44th exportable commodities; huge arable land; etc. and yet stagnated in the first 40 years as a nation (Soludo 2007).

The implications of Vision 2020 is that, Nigeria as a nation is now in competition with other nations in the globe, more importantly competing with 19 other greatest economies of the globe. Nations often engage in entrepreneurship to strengthen performance and further growth of their sustainable economic development through entrepreneurial development (Guth and Ginsberg, 1990; Stevenson and Jarillo, 1990). Recently, many nations have found that entrepreneurial development culture and cognition can provide a major impetus for such efforts. While technology is the very foundation of today's global economy, there is limited understanding of the entrepreneurial development culture that creates technology or of the human qualities that result to economic growth. In light of the competitive strategies today in the globe, where various nations become rivals, many nations are espousing an evolutionary theory of economic growth, which considers indigenous entrepreneurs as the principal instigators of change. With reference to global context, "indigenous entrepreneur" can refer to a local company, cooperative, or individual - whether is one person or group, what matters is the entrepreneurial trait of questioning the status quo and creating fresh alternatives. This is the innovative energy that will ultimately be beneficial to developing economy like ours and leads to a better future for our economy.

The concept of entrepreneurial studies has appreciably changed in nature and content over the years, it is now increasingly becoming more of systematic, purposeful and objective study of cultural variances, values system and economies around us. Entrepreneurial development culture has come to be recognized globally as the key to rapid and sustainable development as well as welfare and progress of mankind since successful economic development does not just happen. It is the result of good entrepreneurial development culture. In fact, in Nigeria, entrepreneurial development is in its cultural ethos. Good entrepreneurial development culture enriches eco-system and gives a boost to economic growth. Economic growth refers to an increase in a country's production or income per capital, with economy's total output of goods and services being measured by Gross National Product (GNP). At this juncture, Nigeria's economy needs much more than growth. Economic development, on the other hand, goes beyond economic growth to include changes in output, distribution and economic structure, which may affect such things as improvement in material well-being of the poor, technical breakthrough, increase in economic activities and increase in educational level etc (Desai 2000).

Although the factors contributing to economic development are labour, technology, natural resources, capital and entrepreneurship, the key factor in this development process is the entrepreneur and the growth of entrepreneurship is the forte of entrepreneurial culture. To become one of the first twenty most industrialized countries in the world by the year 2020, Nigeria must systematically and practically encourage local entrepreneur.

Entrepreneurial culture consists of tangible man made objects and in addition, culture that includes the values, character, qualities, and skill acceptable within a particular society. Hence, culture in a society is learned and is passed on from one generation to the next. Culture is nurtured, fostered and promoted. What accounts for the rise in development are not the external resources such as markets, minerals or factories but the entrepreneurial spirit which exploits the resources - a spirit found most often among business entrepreneurs. Thus, entrepreneurial culture implies vision, values, norms and traits that are conducive for 
the development of the economy (Desai 2005).

Entrepreneurs have heightened ability and awareness for recognizing and audaciously exploiting business opportunities. They persistently and continually seek opportunityladen ideas in order to satisfy internal motivators such as the need for achievement and fulfillment of competitive urges. Actually, entrepreneurship is driven by business challenges that match and stretch human skills, knowledge, and abilities. Entrepreneurial culture influences entrepreneurial development, hence, political and economic ideologies need to be built around values central to entrepreneurship that should focus on capitalist values different from socialist values that discourage entrepreneurs and entrepreneurship, thus, socialist economic-legal structure acts as a road block to entrepreneurship. The former is the rationale behind the risks of entrepreneurship in South Asian countries. One would conclude that there is likely a preference for entrepreneurship inherent in the South Asian culture, unlike Nigeria with large population where there is low spirit of entrepreneurship. In fact, entrepreneurial cultural factor gives rise to South Asian entrepreneurism. In a country where neither the government nor the societal culture encourages ideas, what do you expect? Thus, entrepreneurship culture is a prerequisite to economic development. Hence, there is need for entrepreneurial culture and climate since it influences entrepreneurial environment, entrepreneurial skills and behaviours correlate best with entrepreneurial success (Pech and Cameron 2006).

Experiences from successful entrepreneurs encapsulate the entrepreneurial spirit that researchers have come to recognize. It demonstrates humour in the face of adversity, indicates a sense of robustness, and an ability to bounce back from failure. However, this can only be true in environment/organizations where there is enterprise culture - a society which encourages expertise in failing. That is, successful entrepreneurs are expertise in failing that learned how to happily wallow in incompetence. Any government that wants to provoke entrepreneurship must encourage a 'can-do culture' where failures do not paralyze employees with fear. Thus, failure is undeniable knowledge for entrepreneur to be and societal climate must encourage the study of failure and chase down another role model for the success side of the equation. The foregoing encapsulates the entrepreneurial development culture spirit that researchers have come to recognize.

Entrepreneurial developments need culture to thrive - economic culture that allows people to challenge ideas, suggestions and plans. Nations that encourage and established a culture that reflected a relaxed citizenry style are likely to be more successful. This will lead to the environment of thinking and committed people capable of producing the kind of innovation, and productivity required in today's society. If culture does not allow dissent, if it does not allow mistake and if people who suggest alternatives are castigated for not being team players, then society would produce culture of fear, stagnation and antipathy and this culture affects an economy.

\section{Statement of Problem}

Nigeria, as a country possesses the wherewithal to join the league of the twenty top economies in the world. As at today, Nigeria is one of the biggest economies in the Africa continent with huge resource endowment. The country is heading towards becoming one of the largest economies in the year 2020, but the challenge is: "can Nigeria achieve this goal"? Entrepreneurism is the lifeblood of any economy and entrepreneurship has 
been used today by developed nations as a development tool, but is yet to achieve its potential in Nigeria due to neglects of entrepreneurial development culture. In Nigeria, entrepreneurism is more about overcoming cultural underpinnings having heard about the bureaucratic obstacles to would-be entrepreneurs - be it a culture where we think of ourselves as employees rather than as employers and entrepreneurs; a culture where we are demoralized by failure, thereby affecting the ability to take risk i.e. a culture where creative thinkers are not recognized nor nurtured; a culture where we tell stories of failure entrepreneurs rather than successful entrepreneurs; a culture where entrepreneurs are turning into managers who ought to be innovators and creative thinkers; a culture that does not put people first; a culture of impunity where 'anything goes'; a culture that does not recognize distinctive culture of a society; a culture of business unethical practices; a culture that lacks total quality culture, a culture that lacks cultural changes, a culture that lacks judgment in decision-making - than about achieving the fruits of liberalization. All these aforementioned cannot be an inspiring image for a country that dreams of being classified among the greatest twenty economies by the year 2020 .

\section{Objective of the Study}

The main objective of this study is to ascertain that actualization of Nigeria's vision 20:2020 depends on entrepreneurial development culture. The specific objectives of this study are:

- To ascertain if there is entrepreneurial support system on human capital development towards Vision 20:2020 in Nigeria;

- To ascertain if entrepreneurship and economic development complement each other;

- To ascertain the factors affecting entrepreneurial growth in Nigeria;

- To suggest ways to stimulate entrepreneurial behaviour among individuals in order to actualize Vision 20: 2020 in the Nigerian economy.

\section{Clarification of Concepts as it relates to Economic Development}

For the purpose of this paper, the following concepts need to be clarified for proper understanding.

Entrepreneurship: This is the process through which entrepreneurs create and grow enterprise - this process includes four critical elements: opportunity recognition, idea creation, venture creation and operation, and creative thinking. By and large, it is a process of using private initiative to transform a business concept into a new venture or to grow and diversify an existing venture or enterprise with high growth potential. Entrepreneurs identify an innovation to seize an opportunity, mobilize money and management skills, and take calculated risks to open markets for new products, processes and services. Becoming an entrepreneur means adopting a lifestyle as well as a livelihood. Therefore, entrepreneurs need to know as much about themselves as about their business. This model cultivates an entrepreneurial mindset, developing such aptitudes as initiative, flexibility, perseverance, and resilience along with strategic thinking. Hence, entrepreneurship is one of the critical components necessary to secure economic prosperity for any economy.

Entrepreneurship Development (ED): This is the process through which a structure that 
facilitates and breeds entrepreneurship is built. It is a process of enhancing entrepreneurial skills and knowledge through structured training and institution-building programmemes. ED aims to enlarge the base of entrepreneurs in order to hasten the pace at which new ventures are created. This accelerates employment generation and economic development.

Entrepreneurship Development Culture (EDC): Entrepreneurship provides a way out of a culture of defeat. Entrepreneurial attitudes extend into other areas of life, generating a sense of empowerment and self-determination. Hence, "entrepreneurship/entrepreneurial development culture is about teaching how obstacles can have another meaning; how they can be overpowered and used to advantage; how to never give up and enjoy looking for other ways out." Entrepreneurial development culture is simply "unleashing entrepreneurship"; making it the ideal tool to bridge the gap between entrepreneurship development theory and practice in any economy. A prosperous entrepreneurship culture leads to economic development and creating an entrepreneurial culture requires systems to support lifelong education; acceptance of diverse ideas, people and business; and a commitment to wealth and quality job creation.

Entrepreneurial Development System (EDS): The economy all over the globe has changed. Hence, several economic development programmemes and agencies are emerging. Hence, the government, higher education, non-profits, and the private sectors are coming together to create Arrowhead Entrepreneur Development System (EDS), a comprehensive, cohesive system of service to support the growth of new business formation and the expansion of existing local businesses. The EDS coordinates the existing service providers and fills the support gaps to provide a seamless focused on the needs and skill level of the entrepreneur.

Entrepreneurship: Economic Growth and Development: Entrepreneurship has increasingly been held out as an alternative to traditional economic development strategies and policies. The goals of most economic policies, including economic development policies, are to increase welfare either by reducing the deleterious effects of market failure, or by improving the distribution of income or both. Economic development falls under both of these rationales. Market failure by definition leads to suboptimal economic performance. Economic growth is not only a consequence of policies which eliminate market failures, but growth is itself a public good.

\section{Conceptual Framework}

Entrepreneurship is gaining new recognition as an engine for economic growth. The concept of entrepreneurship evolved over more than two centuries has undergone major changes, yet the concept of entrepreneurship is not clear. As the concept of entrepreneurship is complex in its content, it is influenced not only by economical aspects, but also sociological, political, psychological, ethical, religious and cultural values. The concept also bears testimony to encourage creativity, determination, networking, hard working etc. Entrepreneurship is one of the four mainstreams of economic factors: Land, labour, capital and entrepreneurship. Richard Cantillion 1775, a French economist of Irish descent, is credited with giving the concept of entrepreneurship a central role in economics. Adam Smith spoke of the 
"enterpriser" in his 1776 wealth of nations where he ascribed to the entrepreneur the role of industrialist. In Smith's view, entrepreneurs reacted to economic change, thereby becoming the economic agents who transformed demand into supply. French economist Jean Baptiste Say, in his 1803 Traite d'economie politique (Tratise on Political Economy), described an entrepreneur as one who possessed certain arts and skills of creating on economic enterprises, yet a person who had exceptional insight in society's need and was able to fulfill them. Say, therefore, combined the "economic risk taker" of Cantilion and the "industrial manager" of Smith into an unusual character. Say's entrepreneur influenced the society by creating new enterprises and at the same time was influenced by society to recognize needs and fulfill them through astute management of resources. Carl Menger (1841 - 1921) established the "subjective perspective of economics". In Menger's view, economic change does not arise from circumstances but from an individual's awareness and understanding of those circumstances. The entrepreneur becomes, therefore, the change agent who transforms resources into useful goods and services, often creating the circumstances that lead to industrial growth. Entrepreneurial culture is the functional management process which involves attracting, developing and maintaining a talented and energetic workforce to support nation's vision, mission, objectives and strategies (Schermerhorn, 1999)

Economic development of any economy is an outcome of purposeful human activity. People assume various roles in the development process, namely, as organizer of human capital, natural material resources, worker and consumer. He stands at the centre of the whole process of economic development i.e. he occupies a crucial place in the process of economic development (Dasei 2005). According to Schumpeter (1934) economic development consists of "employing resources in different ways" bringing them in a new combination of means of production. The entrepreneur looks for ideas and puts them into effect for economic development.

The entrepreneur as an economic actor and a driving force for economic development was first emphasized by Austrian economists (Schumpeter, 1934; Kirzner, 1997). Joseph Schumpeter (1934:130) employed an individual level approach to entrepreneurship and viewed entrepreneurs as "revolutionaries of the economy" whose economic function is the "realization of new combinations in the course of which they are the active element" (p.111). Schumpeter also described entrepreneurship as a force of "constructive destruction" whereby established ways of doing things are destroyed by the creation of new and better ways to get things done. Entrepreneurs in many ways personify market forces; one might expect them to be the central figures in economic growth. Similarly, because most entrepreneurial ventures somehow involve a firm that leads to development, entrepreneurship would seem to be a core element of the economic development. However, entrepreneurship has been largely neglected by Nigeria's government in the quest for searching for economic development. Entrepreneurship is invoked in an ad hoc fashion, when needed to explain aspects of society organization (Knight, 1921), economic development (Schumpeter 1911), market dynamics (Kirzner 1973), and leadership (Witt, 1998).

In the academic management literature, entrepreneurship is often associated with boldness, daring, imagination, and creativity (Begley and Boyd, 1987; Chandler and Jansen, 1992; Lumpkin and Dess, 1996). These accounts emphasize the personal, psychological 
characteristics of the entrepreneurial development culture. In this conception, entrepreneurship is not a necessary component of all human decision-making, but a specialized activity that some individuals are particularly well-equipped to perform toward the growth of the society.

Another strand of literature, incorporating insights from economics, psychology, and sociology and leaning heavily on Max Weber, who associates entrepreneurship with leadership (Witt, 1998). Entrepreneurs, in this view, specialize in communication - the ability to articulate a plan, a set of rules, or a broader vision, and impose it on others. The successful entrepreneur excels at communicating these models to others, who come to share the entrepreneur's vision (and become his followers).

While economists have not completely ignored the entrepreneur, there is little consensus about how entrepreneurship should be modeled and incorporated into economic theory. Indeed, the most important contributions to the economic theory of entrepreneurship have generally been viewed as interesting, but idiosyncratic insights that do not easily generalize to other contexts and economic problems. Schumpeter's well-known concept of the entrepreneur as innovator is a prime example. Schumpeter's entrepreneur introduces "new combinations" - new products, production methods, markets, sources of supply, or industrial combinations - shaking the economy out of its previous equilibrium through a process Schumpeter termed "creative destruction."

Realizing that the entrepreneur has no place in the general-equilibrium system of Walras, Schumpeter $(1911,1939)$ gave the entrepreneur a role as the source of economic change.

in capitalist reality as distinguished from its textbook picture, it is not [price] competition which counts but the competition from the new commodity, the new technology, the new source of supply, the new type of organization . . . competition which commands a decisive cost or quality advantage and which strikes not at the margins of profits and the outputs of existing firms but at their foundations and their very lives (Schumpeter, 1942:84).

Schumpeter carefully distinguished entrepreneurs from capitalists. While entrepreneurs could be managers or owners of firms, they are more likely to be independent contractors or crafts-men. In Schumpeter's conception, "people act as entrepreneurs only when they actually carry out new combinations, and lose the character of entrepreneurs as soon as they have built up their business, after which they settle down to run it as other people run their businesses" (Eke-lund and Hébert, 1990:569). Moreover, because Schumpeterian entrepreneurship is sui generis, independent of its environment, the nature and structure of the firm does not affect the level of entrepreneurship. Corporate research and development (RandD) budgets, along with organizational structures that encourage managerial commitment to innovation (Hoskisson and Hitt, 1994), have little to do with Schumpeterian entrepreneurship per se. Kirzner's (1973) concept of entrepreneurship as "alertness" to profit opportunities is another well-known economics approach. The simplest case is that of the arbitrageur, who discovers a discrepancy in present prices that can be exploited for financial gain. In a more typical case, the entrepreneur is alert to a new 
product or a superior production process and steps in to fill this market gap before others. Success, in this view, comes not from following a well-specified maximization problem, but from having some insight that no one else has, a process that cannot be modeled as an optimization problem. As in Schumpeter's vision, Kirzner's entrepreneurs do not own capital; they need only to be alert to profit opportunities. Because they own no assets, they bear no uncertainty, and hence cannot earn losses; failure to discover an existing profit opportunity is the worst that can happen to an entrepreneur. For these reasons, the link between Kirznerian entrepreneurship and the theory of firm organization is weak. Owners, managers, employees, and independent contractors can all be alert to new profit opportunities; Kirzner's entrepreneur does not need a firm to exercise his function in the economy.

\section{Theoretical Foundations of Entrepreneurial Economics and its Relationship to Economic Growth and Development.}

The theoretical link between entrepreneurship and economic growth is usually attributed to the early work of Joseph Schumpeter (1934). Schumpeter's concept of creative destruction provides us with a hypothetical relationship between entrepreneurship and economic growth and development. Schumpeter's concept of "creative destruction" provides us with an assumption of relationship between entrepreneurship and economic growth and development.

\section{The Theory}

The history of entrepreneurial theory (Herbert and Link, 1989; Wenneckers and Thurik, 1999) identifies three schools of thought and three major periods. The schools include "... the German tradition of von Thunen, Schumpeter and Baumol...the (neo) classical tradition of Marshall, Knight and Schultz and...the Austrian tradition of Menger, von Mises, and Kirzner." The three periods include the original period of intellectual development up to the middle of the 20th century, the subsequent period of disinterest in entrepreneurship coinciding with the development of the formal neo-classical theory which has little room for entrepreneurship (Wenneckers and Thurik, 1999), and the last 20 years of resurgent interest. Each school of thought has contributed some useful insights to our understanding of entrepreneurship.

In 1912 Joseph Schumpeter (published in English in 1934), described how entrepreneurs challenge the status quo with superior products and processes. This process of creative destruction makes existing products and processes obsolete, releases resources and, in the long run, leads to greater productivity. According to this line of reasoning, entrepreneurship is a behavior rather than a type of firm or even individual. Entrepreneurial activity can occur in any size firm as well as in start-up ventures. Employment, sales, and income growth is a consequence of entrepreneurship. Successful small firms become large firms because they are entrepreneurial.

Leibenstein (1968) elaborated on the concept of entrepreneurship, and proposed a theory of entrepreneurship-based development. Leibenstein distinguishes between routine entrepreneurship (management of well established businesses) and "new type" or $\mathrm{N}$-entrepreneurship. N-entrepreneurship involves new or under-developed activities where markets are nascent and/or production functions are not fully known. Important roles of 
entrepreneurs are to acquire inputs when markets (financial markets for example) are not well developed, and to fill gaps when information and market mechanisms are incomplete. If markets were perfect, the search, organizational, risk-bearing and other activities of entrepreneurs would be available for sale by intermediaries in competitive markets and would provide opportunities for the generation of economic rent.

While little progress has been made to formalize the more dynamic and disequilibrium conceptualization of entrepreneurship, many of the key ideas can be merged into to an amalgam theory of entrepreneurship. Wenneker and Thurik (1999) conclude with a summary of several theories which serves as a starting point for such an amalgam. Figure one describes a dynamic 'model' of entrepreneurship which identifies three levels at which entrepreneurship may be viewed - the individual (within which entrepreneurship resides), the firm (which serves to internally organize factors of production), and the region (which serve as the external organizer of factors of production) and Figure two identifies three dimension of entrepreneurship - the conditions which lead to entrepreneurship, the attributes of entrepreneurial individuals, firms and regions, and the impact or consequences of entrepreneurship.

These theoretical advances lead to at least two important observations about entrepreneurship. First, entrepreneurship is not just a part of economic development it is the basis of long-term economic development. Second, entrepreneurship is highly place-based. Not only is entrepreneurship shaped by spatial attribute, and not only does it transform the socio-economies of places, but more fundamentally, economic development is less likely to occur in the aggregate if space is not effectively organized into regional/ state entrepreneurial systems.

\section{Reviewing Literature in line with the Objective of the Study}

Entrepreneurial Support System on Human Capital Development towards Vision 20:2020 The Seven Point Agenda of President Yar'Adua emphasized on: Energy emergency; Security of lives and property; Land Reforms; Human capital development; Wealth creation and poverty alleviation; Niger Delta; and Transportation infrastructure. Among the seven point agenda, we are only interested in human capital development as it relates to entrepreneurial culture. In Schultz's formulation, entrepreneurship is the ability to adjust, or reallocate resources, in response to changing circumstances. As such, entrepreneurship is an aspect of all human behaviour, not a unique function performed by a class of specialists. "No matter what part of the economy is being investigated, we observe that people are consciously reallocating their resources in response to changes in economic conditions" (Schultz 1979:2). Businessmen, farmers, housewives, students, and even university presidents, deans, and research directors make Schultz's (1979) list of entrepreneurs.

Entrepreneurship is a function of the gradations of families and society, socio-cultural factors, the environment and effective functioning of the support systems including financial and commercial institutes, research, training extension and consulting services as well as large industrial units interested in developing ancillary industries. Although the industries constitute the most important interested element in entrepreneurship, the possibility of the success of an entrepreneur generally gets enhanced by the efficient and effective operation of the support system. The support systems, therefore, have to be clear about their respective roles, relevant activities and consequent expectations from the 
entrepreneur and they should reinforce values of taking initiative, creativity, searching for alternatives, trying out innovations, planning orientation and risk taking coupled with personal responsibility (Singel 2007:12)

The main role of the support system is to release the energy of the entrepreneur for the main task of setting up an enterprise. This can be achieved, if various hurdles in his way are minimized. If the entrepreneur is involved in unnecessary procedural complexities, his energy for developing and responding to the challenge is unproductively used or blocked. If the support system can help in simplifying procedures and in the availability of necessary information, the entrepreneur can concentrate better on challenges (Singel 2007:12). Motivation is part of entrepreneurial support and this entails desire to do something new, occupational background, educational qualification, technical background, government support and assistance, and availability of factors of production.

\section{Entrepreneurship and Economic Development complement each other}

Entrepreneurship and economic development complement each other. An economic system of a country determines the nature and scope of entrepreneurship. Entrepreneurship can bring about drastic changes in the very structure of the economy. Entrepreneurship works in different economic systems such as capitalism (a capitalist economy represents free enterprises, means freedom to save and invest, free competition, consumer sovereignty and very less interference from the government) - in capitalist system, the entrepreneurs play vital and prominent role in the enterprise because, he controls domestic market by assuming the role of a competitor; socialism (private entrepreneurship is absent in a socialist economic system. Economic and financial experts play important role in the development of entrepreneurship in the system. Such entrepreneurship mainly to serve the society not to mint money or to make profit only) - in this system of economy private entrepreneur has neither a role nor responsibility; and mixed economy (the mixed economy is characterized by co-existence of both the private and public sectors in the same line of production. Consumer goods are left to private enterprises while government undertakes the production of capital goods) - in a mixed economy, restrictions are placed by government to eliminate the problems of monopoly/capitalism. Government under this type of economy curbs the growth of monopolies and encourages competition. Thus, entrepreneurship plays a great and vital role in all major economic systems. Its importance stands beyond challenges and makes huge profit in every economic system (Kumar, Poornima, Mini and Jayashree 2003:9).

\section{Factors Affecting Entrepreneurial Growth}

Failure of individuals to reach their full creative potentials often relates to the inadequate entrepreneurial development growth. The Following are the conditions of environment affecting entrepreneurial growth. These conditions are grouped under two categories: economic conditions and non economic conditions. Economic condition includes capital - capital is the essence of enterprise. Availability of capital facilitates mobility of land, machine, material etc. therefore capital is a lubricant which smoothens the working of vehicle called enterprise; labour - quality and quantity of labour influence the entrepreneurship mobility, dexterity and immobility. Low cost labour and capital intensive technology oriented enterprises influence entrepreneurship; raw material - Availability of 
raw material, nature of industrial establishment, technological innovation and mobility of raw material encourages or curbs the development or entrepreneurship; and market - the potential of the market constitute the major rewards of entrepreneurship from entrepreneurial function. The size and composition of market monopoly in a particular product influence entrepreneurship. Non economic conditions include: social conditions, psychological conditions, and political/government conditions.

\section{Stimulation of Entrepreneurial Behaviour in Nigeria's Environment}

Given that creative people thrive in creative environments, society must strive to ensure that their environment is as nurturing as possible towards enhancing the resident creative collateral. Appropriate leadership, structures, and tasks, all interact with and influence the quantity and quality of creative work carried out by the members of a society. Leadership plays a key role in unleashing the creative power of every citizenry. Empowering people to innovate is one of the most effective ways for leaders to mobilize the energies of people to be creative. Empowerment, when combined with leadership support and commitment, gives people freedom to take responsibility for innovation. A flexible, organic structure, which encourages teamwork, also acts as a stimulant to people to be more creative. The entrepreneur is one of the most important inputs in the economic development of a country and several factors go into the making of entrepreneur. The socio-political and economic conditions, the availability of industrial technology and know-how, state of art and culture of business and trading, existence of markets for products and services and the incentives and facilities available for starting an industry or business, all have a bearing on the growth of entrepreneurship. A conducive environment is created through the policies and interest of the government in economic and industrial development (Dasai 2005).

Modification of entrepreneurial behaviours, entrepreneurial attributes and entrepreneurial skills is essential for the actualization of Nigeria's vision 2020 agenda. Entrepreneurial behaviours such as grasping opportunity, taking initiatives, solving problems creatively, managing autonomously, taking responsibility for and ownership of things, seeing things through, networking effectively to manage interdependence, putting things together, creating and using judgement to take calculated risk. Entrepreneurial attributes entail achievement orientation and ambition, self confidence and self esteem, perseverance, high internal locus of control (autonomy), action orientation, and preference for learning by doing, hard-working, determination and creativity. Lastly entrepreneurial skills entail creative problem solving, persuading, negotiating, selling, proposing, holistically managing business/projects/situations, strategic thinking, intuitive decisionmaking under uncertainty and networking (Desai 2005)

\section{Discussion and Conclusion}

An open, facilitating culture, in which a positive attitude towards creativity prevails, will transmit the message that creative input is appreciated from all levels and functional areas in the society. While it is acknowledged that certain individuals possess highly creative abilities, society must also avoid assuming that creative individuals form a separate elite group, and that citizens may be labeled as "creative" or "uncreative". Unfortunately, many new ideas are rejected or lost because they originate from inappropriate or traditionally unorthodox creative sources. It is clearly a society's best interest to acknowledge and 
foster the creative talent of all its population, as the larger the "catchments area" for new ideas, the greater the possibility of finding successful, innovative solutions in the process of economic development.

A strong, creativity-oriented culture greatly enhances the prosperity of innovation. Cultural aspects favourable to innovation include openness and sharing, teamwork, motivating and engaging people and embedding knowledge management activities in the day-to-day business processes, internal systems and structures. However, care must also be taken to ensure that the culture does not have a negative effect on the economy competitive strength. An adverse culture, for example one in which resistance to change, lack of interest and involvement, incompetence and perceptions of managerial distance prevail, will seriously hinder any creative initiative. The key to success is adaptability, i.e., the ability to recognize and accept change and to deploy the cultural strengths of a nation into competitive operational strategies.

One thing that is evident from this paper is that entrepreneurial culture is critical to rapid economic development if experience in most parts of the world (Europe, Asia, and United State) is anything to go by. It is, in fact said to hold a major key to the emancipation of Nigerian economy from the position of a weak economy, onto the fringes of an emerging economy and towards the classification among the greatest first twenty economies in the globe by the year 2020. With the effort and commitment of Nigeria's Government to revamp the economy, it is imperative to place considerable policy attention on entrepreneurial development culture since the quality and quantity of entrepreneurial culture will determine how our economy growth will translate into one of the greatest first twenty economies in the globe by 2020 . To this end and given the backwardness of Nigerian economy, it is our opinion in this paper that awaking entrepreneurial culture will pave way for distinctive economic growth that will bring about tremendous reduction in absolute poverty or even eradication of the phenomenon, thereby enhancing economic growth and development. This can be enhance through entrepreneurship education, hence, educational programmeme backed up with entrepreneurial foundations and provides opportunity for learning skills, technology and markets. A 2002 report on 16 entrepreneurship initiatives in various developing countries summarized the situation accurately: "it is not a question of whether to give a man a fish or teach him to fish, what is needed to make a real difference is "fishing schools"” (Bridges.org, 2002)

\section{Summary and Recommendation}

This paper has attempted to examine the issue of Nigerian emerging economy as it relates to entrepreneurial culture and vision 20:2020. Creating an entrepreneurial culture requires systems to support lifelong education, acceptance of diverse ideas, people and business, and a commitment to wealth and quality job creation. The entrepreneurial culture can thrive if citizens and leaders craft a strategy to celebrate successes and learn from failures

This study gives a brief overview of the factors that stand as unresolved issue and if the issues are allowed to remain without a solution, vision 20:2020 actualization will stand as a mirage but when the issues at stake - entrepreneurial culture are resolved, Nigeria will not only join the league of twenty top economies in the world by 20:2020 but her dream will call for scenario analysis - peering into the future in order to stimulate new strategic thought about the possible consequences of event. 
The discussion, analysis and reflection presented in this paper are based on the assumption that there is a relationship between the entrepreneurial development culture process and economy development. Indeed, the way this process is managed is a key factor in determining the extent to which an economy can survive and flourish. In the case of Nigeria, there is incontrovertible evidence in this paper to support the assertion that entrepreneurial development culture in Nigeria is the greatest impediment to Nigeria's economic development. But if this is the case, then it is pertinent to consider the implications of the analysis and prescriptions so far, in order to facilitate the actualization of vision 20:2020, thus the following are recommended:

The Nigerian government's interest in economic development should be based on government interest on entrepreneurial development culture of its citizenry, since it is a function of the gradations of families and society. The Nigeria government through its agency Nigeria Universities Commission (NUC) should implement "A Report on a National Sensitization Workshop on Entrepreneurship Development in Nigerian Universities, Organized by the NUC in Collaboration with the National Board for Technology Incubation (NBTI) from 21st to 22nd May 2008 held in Idris Abdukadir Auditorium in NUC office, Abuja". In the workshop, awareness about entrepreneurial development as a career option in higher institutions was emphasized and the participants were reminded of the policy thrusts of the federal government: that the mandatory introduction of entrepreneurship education in all institutions of higher leaning in Nigeria is seen by her as a sine-qua-non for the objectives of Vision 20-2020. Once, this is implemented, the seeds of entrepreneurship will be planted in higher education and when the class of 2020 graduates from higher institution in Nigeria, this generation will have grown up a nation where business success and entrepreneurship are recognized and valued. Entrepreneurship will be an equal choice, as they plan their education and economic future, with wage employment. They will have the skills and the confidence to create work (job or business) wherever they choose to live. But we hope that they will choose to stay in Nigeria.

Since entrepreneurial development and economic development complement each other, both should be seen as a 'Siamese twins' to economic growth. Hence, our mixed economy system should be a facilitator and not a hindrance to entrepreneurial development culture. That the mixed economy system we operate should bring into line the spirit of capitalist economy system that unlocks the factors responsible for entrepreneurial growth That the modification of entrepreneurial behaviours, attributes and skills is essential for the actualization of Nigeria's vision 20:2020. Nigerian government should be able to identify risks and determine the likelihood of success, identifying the factors that affect the levels of entrepreneurship in a country. Hence, the government should encourage entrepreneurial development culture by creating basic facilities, utilities and services by providing incentives and concessions. In Nigeria, promising entrepreneurs should be nurtured and helped to serve as a role models and mentors for their communities and the nation in general. Rather than designing top-down aid programmemes to improve living conditions and create jobs in traditional industries, Nigerian government and NGOs should focus on creating a business environment conducive for private investment and entrepreneurial activity. This is a primary recommendation of a 2004 United Nations Report: Unleashing Entrepreneurship: Making Business Work for the Poor. The Nigerian government should depend on its citizenry in actualizing vision 20:2020 rather than depending on foreigners, 
since self-help is the best form of assistance a person can give to himself. The implication of this statement is that: to make Nigeria's development a reality, Nigerians home and those in Diaspora have to makes the reality of our time and place the basis of the choice of our development options - Nigerians would have to be architects of their own development. This is how Professor Adebayo Adedeji, erstwhile Executive Secretary of the Economic Commission for Africa (ECA), aptly expresses it: "Europeans developed Europe, Americans transformed America and Japanese developed Japan, and so only Africans themselves can develop Africa. We can only be assisted by foreign development partners (Adabayo 1990: ix).

The Nigeria's government should put its people first towards the actualization of vision 20:2020. It become clear from the discussion of this paper that development is nothing but human development. This is a point Dr. Julius Nyerere, first president of the republic of Tanzania, opines in his essay on Freedom and Development when he writes thus: "Roads, buildings, the increase of the crop output, and other things of this nature, are not development: they are tools of development. A new road extends a man's freedom if he travels upon it. An increase in the number of the school buildings is development only if those buildings can be, and are being used, to develop the minds and the understanding of the people. An increase in the output of wheat, maize or beans is only development if it leads to the better nutrition of the people. An expansion of cotton, coffee or sisal crop is development only if these things can be sold, and the money used for other things which improve the health, comfort and understanding of the people. Development which is not development of the people may be of interest to historians in the year 3,000: it is irrelevant to the future which is being created. (Cited by Olusegun 2008:18). x. The Association of Academic for Entrepreneurial Studies (AES), in Nigeria should be given adequate support and legal backing by Nigeria government, since the main thrust of the institution is the development of leadership and entrepreneurial sprit in all fields of endeavour.

\section{References}

Adebayo, A. (1990). Alternatives Development Strategies for Africa, Foreward in Bade Onimode (ed.), Vol. 1 Londom: Institute of Africa Alternative, p.ix

Audretsch, D. B. (1995). Innovation and Industry Evolution. Cambridge, MA: MIT Press.

Begley, T. M., and Boyd, D. P. (1987). Psychological Characteristics Associated with Performance in Entrepreneurial Firms and Smaller Businesses. Journal of Business Venturing. 2: 79-93.

Cantilion, R. (1931). Essai sur la nature du commerce en general, Translated by Higgs H., London: Macmillan, pp 47 - 49, 53, and 151 - 153. Cited by Holt D.H. (1992). Entrepreneurship New Venture Creation. New Delhi - India, Prentice - Hall.

Chandler, G.N., and Jansen, E. (1992). "The Founder's Self-Assessed Competence and Venture Performance." J. Bus. Venturing 7: 223-36.

Desai, V. (2005). Dynamics of Entrepreneurial Development and Management. Mumbai: Himalaya Publishing House.

Eisenhardt, K.M., and Martin, J.A (2000). “Dynamic Capabilities: What are They?". Strategic Management Journal, 21: 105-1121.

Ekelund, R.B., Jr., and Hébert, R.F. (1990). A History of Economic Thought and Method, third edition. New York: McGraw-Hill.

Guth, W. and Ginsberg, A. (1990). Guest editor's introduction: Corporate Entrepreneurship. Strategic Management Journal, 11: 5-15.

Hoskisson, R.E., and M.A. Hitt. (1994). Downscoping: How to Tame the Diversified Firm. New York: 
Oxford University Press.

Johnson T.G. (2006). Measuring the Returns to Rural Entrepreneurship Development, Paper presented at the Exploring Rural Entrepreneurship: Imperatives and Opportunities for Research Conference, Washington, DC, October 26.

Julius K. Nyerere, (1974). Man and Development, Dares Salaam: Oxford University Press, cited in Olusegun Oladipo (2008). The Need for Social Philosophy in Africa, 17th Convocation Lecture, Delivered at Ambrose Alli University, Ekpoma - Nigeria.

Kirzner, I. M. (1997). Entrepreneurial Discovery and the Competitive Market Process: An Austrian Approach. Journal of Economic Literature, 35(March): 60-85.

Kirzner, I.M. (1973). Competition and Entrepreneurship. Chicago: University of Chicago Press.

Knight, F.H. (1921) Risk, Uncertainty, and Profit. New York: August M. Kelley press.

Kumar, S.A., Poorinima, S.C., Mini, K.A., and Jayashree K. (2003). Entrepreneursip Development. New Delhi - India: New Age International (P) ltd.' Publishers.

Leibenstein, H. (1968). Entrepreneurship and Development. The American Economic Review (Papers and Proceedings) 58: 72-83.

Lumpkin, G. T., and Dess, G. G. (1996). Clarifying the Entrepreneurial Orientation Construct and Linking it to Performance. Academy of Management Review, 21(1), 135-172.

Menger, C. (1950). Principles of Economics, Translated by Dingwall J. and Hoselitz D.F (Glencose, IL: Free Press, 1950). Pp.8 - 14, 56 - 57. Cited by Holt D.H. (1992). Entrepreneurship New Venture Creation. New Delhi - India, Prentice - Hall.

Pech, R.J., and Cameron A. (2006), "An Entrepreneurial Decision Process Model Describing Opportunity Recognition”, In European Journal of Innovation Management, 9(1), 61-78.

Say, J. B. (1803). A Treatise on Political Economy, 4th ed., Translated by Prinsep C.R (Philadephia: Grigg and Ellot, 1845). Pp. 99 - 100, 127, 330 - 332. Cited by Holt D.H. (1992). Entrepreneurship New Venture Creation. New Delhi - India, Prentice - Hall.

Schultz, T.W. (1979). "Concepts of Entrepreneurship and Agricultural Research.” Kaldor Memorial Lecture, Iowa State University, October.

Schumpeter, J.A. (1911). The Theory of Economic Development: An Inquiry into Profits, Capital, Credit, Inter-est, and the Business Cycle. Translated by Redvers Opie. Cambridge, Mass.: Harvard University Press.

Schumpeter, J.A. 1934. The Theory of Economic Development An inquiry into profits, capital, credit, interest and the business cycle (English Translation of 1912 German language volume), Harvard University Press.

Schumpeter, J.A. (1939). Business Cycles: A Theoretical, Historical and Statistical Analysis of the Capitalist Process. New York: McGraw-Hill.

Schumpeter, J.A. (1942). Capitalism, Socialism, and Democracy. New York: Harper and Row.

Singel, R.K. (2007). Entrepreneurship Dvelopment and Management. Delhi, S.K. Kataria and Sons.

Soludo, C.C (2007). Nigerian Economy: Can we achieve Vision 20: 2020? Seminar Presented by CBN Governor 8th January

Stevenson, H.H. and Jarillo, J.C. (1990). A paradigm of Entrepreneurship: Entrepreneurial management. Strategic Management Journal, 11(Special issue), 17-27.

Thurik, R., and Wennekers S. (2001). A Note on Entrepreneurship, Small Business and Economic Growth. ERS-2001-60-STR, Erasmus Research Institute of Management (ERIM) Report Series, Research in Management. October. https://ep.eur.nl/handle/1765/125

Wennekers, A.R.M,. and Thurik, A.R. (1999). "Linking Entrepreneurship and Economic Growth," Small Business Economics, Vol. 13, 27-55.

Witt, U. (1988). "Imagination and Leadership: The Neglected Dimension of an Evolutionary Theory of the Firm." J. Econ. Behaviour and Organization 35: 161-77.

Yate, M. (1991). Keeping the Best and other Thoughts on Building a Super Competitive Workforce, Holbrook, M.A., Bob Adams Inc, in Bello-Imam, Oshionebo and Ojeifo (2007) (eds.) in 
Fundamental of Human Resources Management Introduction and Synopses of Chapters Fundamental of Human Resource Management in Nigeria.

Stevenson, H.H. and Jarillo, J.C. (1990). A paradigm of Entrepreneurship: Entrepreneurial management. Strategic Management Journal, 11(Special issue), 17-27.

Thurik, R., and Wennekers S. (2001). A Note on Entrepreneurship, Small Business and Economic Growth. ERS-2001-60-STR, Erasmus Research Institute of Management (ERIM) Report Series, Research in Management. October. https://ep.eur.nl/handle/1765/125

Wennekers, A.R.M,. and Thurik, A.R. (1999). "Linking Entrepreneurship and Economic Growth," Small Business Economics, Vol. 13, 27-55.

Witt, U. (1988). "Imagination and Leadership: The Neglected Dimension of an Evolutionary Theory of the Firm.” J. Econ. Behaviour and Organization 35: 161-77.

Yate, M. (1991). Keeping the Best and other Thoughts on Building a Super Competitive Workforce, Holbrook, M.A., Bob Adams Inc, in Bello-Imam, Oshionebo and Ojeifo (2007) (eds.) in Fundamental of Human Resources Management Introduction and Synopses of Chapters Fundamental of Human Resource Management in Nigeria. 